\title{
Descending Limb of Henle's Loop
}

National Cancer Institute

\section{Source}

National Cancer Institute. Descending Limb of Henle's Loop. NCI Thesaurus. Code C32456.

The descending limb of the U-shaped portion of the renal tubule. 